\title{
The use of equine chorionic gonadotropin in the treatment of anestrous dairy cows in gonadotropin-releasing hormone/progesterone protocols of 6 or 7 days
}

\author{
M. A. Bryan, ${ }^{\star 1}$ G. Bó,† R. J. Mapletoft,ł and F. R. Emslie§ \\ *VetSouth Ltd., Winton, Southland 9718, New Zealand \\ †Instituto de Reproducción Animal Córdoba (IRAC), Cordoba 5145, Argentina \\ ¥Western College of Veterinary Medicine, University of Saskatchewan, Saskatoon, SK, S7N 5B4, Canada \\ §Bomac Laboratories Ltd., Manukau, Auckland 2241, New Zealand
}

\section{ABSTRACT}

In seasonally calving, pasture-based dairy farm systems, the interval from calving to first estrus is a critical factor affecting reproductive efficiency. This study evaluated the effects of equine chorionic gonadotropin (eCG) on the reproductive response of lactating, seasonally calving dairy cows diagnosed with anovulatory anestrus by rectal palpation. Cows on 15 commercial dairy farms were selected for initial inclusion based on nonobserved estrus by $7 \mathrm{~d}$ before the planned start of mating. All cows were palpated rectally and evaluated for body condition score and ovary score, and were included for treatment according to the trial protocol if diagnosed with anovulatory anestrus. All cows received a standard anestrous treatment protocol consisting of insertion of a progesterone device, injection of $100 \mu \mathrm{g}$ of $\mathrm{GnRH}$ at the time of device insertion, and injection of $\mathrm{PGF}_{2 \alpha}$ at device removal (GPG/P4). Cows were randomly assigned to 1 of 2 groups ( $6 \mathrm{~d}$ or $7 \mathrm{~d}$ ) for duration of progesterone device insertion. Within each of these groups, cows were further randomly assigned to receive either $400 \mathrm{IU}$ of eCG at device removal or to remain untreated as controls, resulting in a $2 \times 2$ arrangement of treatment groups: (1) 6-d device and no eCG ( $\mathrm{n}=$ 484); (2) 6-d device and eCG $(\mathrm{n}=462)$; (3) 7-d device and no eCG ( $\mathrm{n}=546)$; and (4) 7-d device and eCG (n $=499$ ). Cows were detected for estrus from the time of progesterone device removal and were inseminated; those not detected in estrus within $60 \mathrm{~h}$ after progesterone device removal received $100 \mu \mathrm{g}$ of $\mathrm{GnRH}$ and were inseminated at $72 \mathrm{~h}$. The primary outcomes considered were proportion of cows conceiving within $7 \mathrm{~d}$ of the beginning of breeding (7-d conception rate; 7-d CR), proportion pregnant within $28 \mathrm{~d}$ (28-d in calf rate; $28-\mathrm{d}$ ICR), and days to conception (DTC). We found no significant differences between the 6- and 7-d insertion

Received February 20, 2012.

Accepted September 3, 2012.

${ }^{1}$ Corresponding author: markb@thevets.co.nz periods and found no 6 - or 7 -d insertion period $\times$ eCG treatment interactions. Inclusion of eCG into either length of GPG/P4 protocol increased 7-d CR (36.0 vs. $30.6 \%$ ) and 28-d ICR (58.6 vs. $52.3 \%$ ) and decreased median days to conception. The use of eCG in GPG/P4 breeding protocols will improve reproductive efficiency in seasonally calving, anestrous dairy cattle.

Key words: equine chorionic gonadotropin, anestrus, progesterone, gonadotropin-releasing hormone

\section{INTRODUCTION}

Anovulatory anestrus (AnA) is a major barrier to efficient reproduction in both seasonally and nonseasonally calving dairy herds. In seasonally calving herds in particular, the window of opportunity for cows to conceive is approximately $90 \mathrm{~d}$, and the wastage of cows that do not conceive in this period is high (Rhodes et al., 2003).

Under New Zealand conditions, anestrous cows are defined as those that have failed to express visible signs of estrus before the planned start of mating (PSM). The PSM is a defined date for seasonally calving herds when breeding commences, timed to optimize pasture growth in the following spring at the time of parturition. Normally, breeding continues for a period of 6 to $12 \mathrm{wk}$ and is typically split into a 6 -wk period of AI, followed by a 6 -wk period where bulls remain with the herd. Thus, the window for conception is limited, and cows that express behavioral estrus at the beginning of this period are more likely to be mated and conceive than cows that are anestrous at the start of this period (Westwood et al., 2002; Rhodes et al., 2003).

Because pasture-based dairy cattle spend a large proportion of their time outside and away from human observation, anestrus is commonly determined practically in the field in New Zealand by the use of tailpaint, typically applied $4 \mathrm{wk}$ before the PSM. The tailpaint is inspected daily or twice daily at milking. Cows expressing signs of estrous activity normally rub the tailpaint 
off to some degree, and this is used as a primary indicator of estrous activity before the PSM (Smith and Macmillan, 1978). Cows not expressing estrous activity over a period of 3 to 4 wk before PSM are normally presented for veterinary examination to confirm their reproductive status. Anovulatory anestrus is defined as the absence of a corpus luteum (CL) detected by rectal palpation following an absence of signs of estrus (McDougall, 2001). This clinical diagnosis may be augmented by a reduced ovarian size (Morris and Day, 1994) and the absence of follicles $>10 \mathrm{~mm}$ in diameter.

In New Zealand, the proportion of anestrous cows determined by farmer observation has been reported to be $27 \%$ and more than $50 \%$ in some herds (Rhodes et al., 2003). Hormonal intervention for AnA is effective, and over the years, programs have been refined to provide satisfactory responses in terms of both resumption of ovarian activity and improvement in reproductive outcomes (Day and Macmillan, 1995; Hanlon et al., 2000; McDougall et al., 2005). Since the removal of estradiol benzoate (EB) from use in food-producing animals in New Zealand (Lane et al., 2009), the use of a 7-d progesterone device within a GnRH-based regimen ( $\mathrm{GnRH}$ administration and progesterone device on $\mathrm{d}$ 0 ; removal of the device and administration of $\mathrm{PGF}_{2 \alpha}$ on d 7; GnRH on d 9; GPG/P4 program) has been investigated and reported to give 21-d pregnancy rates of $50.9 \%$ (McDougall, 2010).

A previous New Zealand study showed that the use of $400 \mathrm{IU}$ of equine chorionic gonadotropin (eCG) on d 8 of an estradiol-based anestrous treatment protocol (8-d progesterone device, $2 \mathrm{mg}$ of EB on $\mathrm{d} 0$, and $1 \mathrm{mg}$ of EB on d 9) tended to increase conception rates and significantly increased 7- and 28-d in-calf rates (ICR), especially in cows more than 5 yr of age (Bryan et al., 2010). With the loss of EB and the introduction of new anestrus protocols, this study was designed to examine both the role of eCG within a GPG/P4 treatment regimen and the effect of altering the interval from progesterone device insertion to removal to either 6 or $7 \mathrm{~d}$.

\section{MATERIALS AND METHODS}

\section{Power Analysis and Farm Selection}

This study was performed under the auspices of the Invermay Animal Ethics Committee (approval number $\mathrm{AE}$ 11280). Based on a previous study on the treatment of AnA dairy cows in New Zealand, in which eCG improved ICR by $6 \%$ (Bryan et al., 2010), power analysis (Freedman, 1982) indicated that 647 cows were needed in each of the 2 main treatment groups. If ICR changed by $5 \%$, group size would need to increase to 931 cows (both at $\alpha=0.05, \beta=0.8$ ). Experience with coordinat- ing similar large-scale field trials indicated that 10 to $15 \%$ of cows could be lost because of incomplete data sets. To offset this, we enrolled approximately 1,000 cows to each of the 6-d and 7-d protocols in the present trial.

Fifteen farms were selected from the Southland area of New Zealand. Selection was based on having a history of a planned early-intervention strategy for anestrous cows, including early identification before PSM, a willingness to cooperate with trial protocols, and a likelihood that data would be collected with minimal problems. Farms had varying PSM dates, but all were within 3 wk in October and November 2007. Although all were typical New Zealand pasture-based farms, with $>80 \%$ (by DM) of the diet comprising pasture and forage, there were minor variations in feeding strategies among farms.

\section{Study Design and Treatment Groups}

This study was a randomized block, blinded, clinical field trial. The anestrous treatment protocol was timed so that cows in most herds would express estrus within the first $72 \mathrm{~h}$ of PSM. Anestrous cows were preselected based on nonobservance of estrus following tailpaint application before PSM. Preselected cows were screened based on the following inclusion criteria before rectal palpation: no history of observed estrus in the proceeding 21- to 28 -d period; a BCS $>3.5$ (scale of 1 to 10; Macdonald and Macmillan, 1993); more than $28 \mathrm{~d}$ from calving to PSM (i.e., $>21 \mathrm{~d}$ from calving to presentation); and clinically healthy.

Rectal palpation by an experienced veterinarian was then undertaken to determine enrollment into the study based on the following clinical criteria: no detectable CL upon rectal palpation; ovary size $<3$ by ovary score (score 1 to 3 based on ascending size; Morris and Day, 1994); and no discernible pathology (e.g., pyometra, endometritis).

All cows received an intravaginal progesterone-releasing device containing $1.56 \mathrm{~g}$ of progesterone (Cue-Mate, Bioniche Animal Health, Armidale, Australia) and all were treated with a modified GPG protocol (GPG/ P4 program): $100 \mu \mathrm{g}$ of gonadorelin (Ovurelin, Bomac Laboratories, Manakau City, New Zealand) at the time of progesterone device insertion and $500 \mu \mathrm{g}$ of sodium cloprostenol ( $\mathrm{PGF}_{2 \alpha}$; Ovuprost, Bomac Laboratories) at progesterone device removal. Duration of insertion of the progesterone device was randomly divided into either 6 or $7 \mathrm{~d}$; groups were further randomly subdivided to be treated intramuscularly with $400 \mathrm{IU}$ of eCG (Pregnecol, Bioniche Animal Health) at the time of progesterone device removal or as untreated controls in a $2 \times 2$ factorial design. Thus, the following 4 treat- 
ment groups were produced: (1) 6-d GPG/P4 program (6D); (2) 6-d GPG/P4 program with eCG at device removal (6D-e); (3) 7-d GPG/P4 program (7D); and (4) 7 -d GPG/P4 program with eCG at device removal (7D-e).

Following $\mathrm{PGF}_{2 \alpha}$ administration and removal of the progesterone-releasing devices, detection of estrus was practiced; GnRH was scheduled to be administered at $60 \mathrm{~h}$ and fixed-time AI (FTAI) was scheduled to occur at $72 \mathrm{~h}$ for all cows not observed in estrus. All cows detected in estrus within $60 \mathrm{~h}$ after device removal were inseminated $12 \mathrm{~h}$ later and did not receive GnRH ("premated" group). The remainder of cows received GnRH at $60 \mathrm{~h}$ and FTAI at $72 \mathrm{~h}$.

Following stratification, assignment to the 4 primary groups was based upon a preordered list constructed using the RAND function within Excel (Microsoft Corp., Redmond, WA). All interventions were performed by experienced veterinarians or trained technicians, and all inseminations were performed by trained, commercial technicians.

\section{Postbreeding Observations}

Estrus detection continued for at least 4 wk following removal of the progesterone-releasing devices, and all cows detected in estrus were re-inseminated and recorded. Ten weeks after removal of the progesteronereleasing devices, all cows were scanned ultrasonically to detect and determine stage of pregnancies. Using a linear rectal probe attached to an Aloka SSD 500V ultrasound machine (Hitachi Aloka Medical Ltd., Wallingford, CT), all pregnancies were aged in days by an experienced veterinarian and recorded on preformatted sheets by veterinary technicians, before being entered into an Excel spreadsheet (Microsoft Corp.). These pregnancy data were compared with the mating records to determine the exact conception date. When 2 mating dates occurred within $7 \mathrm{~d}$ of each other, the second (later) date was assumed to be correct for data analysis. This occurred in 26 of the 1,991 cows $(6 \mathrm{D}=$ 8 cows; $6 \mathrm{D}-\mathrm{e}=5$ cows; $7 \mathrm{D}=6$ cows; $7 \mathrm{D}-\mathrm{e}=7$ cows).

\section{Data Collection and Outcome Variables of Interest}

Data were collated using Excel and transferred to SPSS 15.0 (SPSS Inc., Chicago, IL) for statistical analysis. The primary outcome variables of interest were 7 -d conception rate ( $\mathbf{7}$-d $\mathbf{C R}), 28$-d in calf rate (28-d ICR), and days to conception (DTC; mean and median). For seasonally calving, pasture-based dairy systems, a key measure of reproductive efficiency is the rate by which cows conceive following PSM. In this study, all cows were inseminated following the GPG/ P4 program. Estrus detection continued after the first insemination, and any cows identified in estrus were inseminated as detected. It is understood that not all cows are synchronized to a GPG/P4 program; thus, we measured the proportion of cows that conceived within $7 \mathrm{~d}$ of finishing the program (7-d CR) and the proportion of cows that conceived over the first $28 \mathrm{~d}$ following completion of the program (28-d ICR). These outcome variables identified the initial response to treatment (whether synchronized or not) and whether any response was lost or intensified by the second cycle following treatment.

\section{Statistical Analyses}

All groups were initially assessed for similarity with regard to hypothesized risk factors, using $\chi^{2}$ for dichotomous data and $t$-tests or one-way ANOVA for continuous variables. All variables and first-order interactions with a probability of $P<0.2$ were included in the final multivariate analyses. Days calved included some cows that had calved more than 12 mo $(\mathrm{n}=42)$, and was initially analyzed as a continuous variable, but was included in the final modeling process as a 2-level risk factor, dichotomized around the biologically important value of $42 \mathrm{~d}$. Age was categorized into 3 groups: 2-yrolds, 3 - to 5 -yr-olds, and $\geq 6$-yr-olds. The premating group was used as a binary variable dichotomized into the presence of observed estrus and subsequent AI before FTAI, or otherwise following the normal program of GnRH on d 9 and FTAI on d 10. Duration of progesterone device insertion and eCG treatment were each used as binary outcomes. All hypothesized risk factors were examined at the univariate level before inclusion in a final multivariate model. For both the 7-d CR and the 28-d ICR analyses, a generalized estimating equation was used to allow for the clustering of cows within farms, with cow within farm as the subject. A binary logistic model was used, with a Type III analysis type and an independent correlation matrix. Goodness of fit was assessed using the quasi likelihood under independence model criterion (QIC), with the lowest value indicating the best model fit. Estimated marginal means (EMM) were produced from the final model, with $95 \%$ confidence intervals.

For the DTC analysis, hypothesized risk factors were first assessed using Kaplan-Meier analysis, and those with a probability of $P<0.2$ at the univariate and first-order interaction level were included in the final Cox proportional hazard model using a forward conditional approach. Variables used in the initial model building were duration of progesterone device insertion, 
Table 1. Herd size and number and proportion of cows presented and treated by farm

\begin{tabular}{|c|c|c|c|c|c|c|}
\hline $\begin{array}{l}\text { Farm } \\
\text { code }\end{array}$ & $\begin{array}{l}\text { Herd } \\
\text { size }\end{array}$ & $\begin{array}{c}\text { No. } \\
\text { presented }\end{array}$ & $\begin{array}{l}\text { Presented } \\
\text { (\% of herd) }\end{array}$ & $\begin{array}{l}\text { Total } \\
\text { treated }\end{array}$ & $\begin{array}{c}\text { Treated } \\
(\% \text { of herd })\end{array}$ & $\begin{array}{c}\text { Treated } \\
\text { (\% of } \\
\text { presented) }\end{array}$ \\
\hline 1 & 1,000 & 354 & 35.4 & 215 & 21.5 & 60.7 \\
\hline 2 & 360 & 144 & 40.0 & 91 & 25.3 & 63.2 \\
\hline 3 & 1,100 & 221 & 20.1 & 165 & 15.0 & 74.7 \\
\hline 4 & 950 & 170 & 17.9 & 105 & 11.1 & 61.8 \\
\hline 5 & 860 & 268 & 31.2 & 176 & 20.5 & 65.7 \\
\hline 6 & 900 & 259 & 28.8 & 163 & 18.1 & 62.9 \\
\hline 7 & 820 & 393 & 47.9 & 236 & 28.8 & 60.1 \\
\hline 8 & 2,171 & 520 & 24.0 & 368 & 17.0 & 70.8 \\
\hline 9 & 630 & 160 & 25.4 & 130 & 20.6 & 81.3 \\
\hline 10 & 600 & 110 & 18.3 & 85 & 14.2 & 77.3 \\
\hline 11 & 470 & 165 & 35.1 & 99 & 21.1 & 60.0 \\
\hline 12 & 680 & 173 & 25.4 & 141 & 20.7 & 81.5 \\
\hline 13 & 350 & 80 & 22.9 & 37 & 10.6 & 46.3 \\
\hline 14 & 380 & 100 & 26.3 & 70 & 18.4 & 70.0 \\
\hline 15 & 790 & 204 & 25.8 & 107 & 13.5 & 52.5 \\
\hline Total & 12,061 & 3,321 & 27.5 & 2,188 & 18.1 & 65.9 \\
\hline
\end{tabular}

eCG treatment, farm, age (recoded into 3 groups of 2 yr, $3-5 \mathrm{yr}$, and $\geq 6 \mathrm{yr}$ ), premating group, and days calved (dichotomized around $42 \mathrm{~d}$ ).

In total, 3,321 cows on 15 farms were presented for inclusion in the study (i.e., this represented $27.5 \%$ of cows on these farms as not having been observed in estrus, ranging from 17.9 to $47.9 \%$ ). All were palpated per rectum, and $2,188(65.9 \%)$ of those presented were deemed AnA (i.e., mean AnA rate per farm of $18.1 \%$, ranging from 10.6 to $25.3 \%$; Table 1), and were randomly assigned to 1 of the 4 treatment groups. Of those treated, 197 cows $(9.0 \%)$ were lost between enrollment and analysis. Causes of loss were progesterone device loss $(\mathrm{n}=9)$, death, culled, lost ear tags, misread ear tags, not drafted at any of the 3 subsequent visits (n
$=81)$, or incomplete data $(\mathrm{n}=107)$, leaving 1,991 cows used in the final (treatment) data set. The final numbers and crude 7-d CR and 28-d ICR per farm are detailed in Table 2.

\section{RESULTS}

\section{Preliminary Data Set}

Treatment groups did not differ significantly with regard to the numbers of exclusions. Treatment groups did not differ with respect to the hypothesized risk factors before the study, with the exception of days calved, which showed significant between farm variation $(P<$ 0.001 ). Overall, $21.1 \%$ of cows were 2 -yr-olds (within-

Table 2. Number of cows used and crude 7-d conception rate (CR) and 28-d in-calf rate (ICR) of cows used in the analysis of treatment effects by farm

\begin{tabular}{lcccccc}
\hline $\begin{array}{l}\text { Farm } \\
\text { code }\end{array}$ & $\begin{array}{c}\text { No. used } \\
\text { in analysis }\end{array}$ & $\begin{array}{c}\text { Used } \\
\text { (\% of enrolled) }\end{array}$ & $\begin{array}{c}\text { 7-d } \\
\text { CR }^{1}\end{array}$ & $\begin{array}{c}\text { Proportion } \\
\text { 7-d CR (\%) }\end{array}$ & $\begin{array}{c}\text { 28-d } \\
\text { ICR }^{2}\end{array}$ & $\begin{array}{c}\text { Proportion } \\
\text { 28-d ICR (\%) }\end{array}$ \\
\hline 1 & 185 & 86.1 & 52 & 28.1 & 78 & 42.2 \\
2 & 76 & 83.5 & 15 & 19.7 & 39 & 51.3 \\
3 & 137 & 83.0 & 47 & 34.3 & 71 & 51.8 \\
4 & 99 & 94.3 & 38 & 38.4 & 61 & 61.6 \\
5 & 166 & 94.3 & 70 & 42.2 & 105 & 63.3 \\
6 & 144 & 88.3 & 38 & 26.4 & 78 & 54.2 \\
7 & 220 & 93.2 & 96 & 43.6 & 142 & 64.5 \\
8 & 358 & 97.3 & 89 & 24.9 & 170 & 47.5 \\
9 & 118 & 90.8 & 58 & 49.2 & 89 & 75.4 \\
10 & 76 & 89.4 & 25 & 32.9 & 40 & 52.6 \\
11 & 87 & 87.9 & 39 & 44.8 & 54 & 62.1 \\
12 & 136 & 96.5 & 33 & 24.3 & 47 & 34.6 \\
13 & 36 & 97.3 & 15 & 41.7 & 23 & 63.9 \\
14 & 66 & 94.23 & 16 & 24.2 & 35 & 53.0 \\
15 & 87 & 81.3 & 30 & 34.5 & 49 & 56.3 \\
Total & 1,991 & 91.0 & 661 & 33.2 & 1,081 & 54.3 \\
\hline
\end{tabular}

${ }^{1}$ Proportion conceiving within $7 \mathrm{~d}$ following treatment program for anestrus.

${ }^{2}$ Proportion pregnant within $28 \mathrm{~d}$ following treatment program for anestrus. 


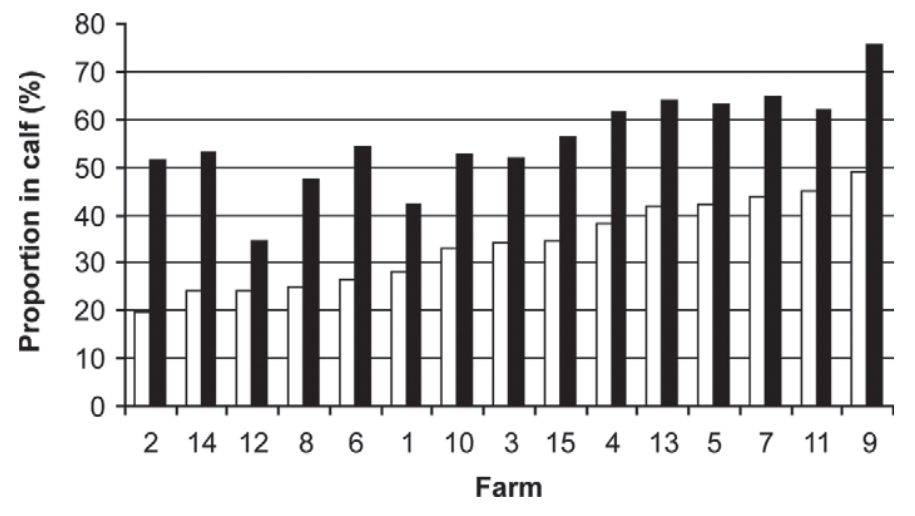

Figure 1. Crude 7-d conception rate (7-d CR; open bars) and 28-d in-calf rate (28-d ICR; solid bars) by farm, ranked by ascending 7-d CR.

farm range, 5.3 to $48.2 \%$ ), $49.5 \%$ were 3 - to 5 -yr-olds (within-farm range, 22.6 to $69.0 \%$ ), and $29.4 \%$ were $\geq 6$-yr-olds (within-farm range, 5.6 to $59.7 \%$ ).

The mean interval from calving to progesterone device removal was 67.6 (SD 15.1) d, ranging from 58.3 (SD 16.3) to 75.5 (SD 10.1) d among farms. Crude ICR also varied widely from farm to farm, with the 7-d CR ranging from 19.7 to $49.2 \%$, and the 28 -d ICR ranging from 34.6 to $75.4 \%$. However, ranking of farms according to crude 7-d CR and 28-d ICR did not produce the same ranking for both outcomes (Figure 1).

\section{Estrus Detection}

In total, 484 cows were detected in estrus before FTAI and were inseminated without receiving GnRH. However, wide variation was observed between farms in the proportion of cows observed in estrus before FTAI (mean 24.3\%; range 0 to $45.8 \%$ ). The proportion of cows observed in estrus during this interval was lower $(20.0 \%)$ in the 6D group than in the other 3 groups, but this difference was not significant $(P=0.075)$.

\section{7-d CR}

The 7-d CR was greater in the eCG-treated groups $(36.0 \%$, 95\% CI: 31.0-41.0\%) than in the non-eCG- treated groups $(30.6 \%, 95 \%$ CI: $25.8-35.5 \% ; \quad P=$ $0.021)$, greater in cows calved longer than $42 \mathrm{~d}(39.8 \%$; 95\% CI: 37.0-42.6\%) than in cows calved less than 43 d $(27.3 \% ; 95 \%$ CI: $20.0-34.6 \% ; P=0.003)$, and greater in cows aged 2 yr $(39.7 \%$; $95 \%$ CI $33.4-46.0 \%)$ than in cows aged 3 to 5 yr $(32.5 \%$; $95 \%$ CI: $27.8-37.2 \%)$, or 6 yr and older (28.1\%; 95\% CI: $23.0-33.2 \%$; $P=0.001)$.

The group of cows observed in estrus and inseminated either before FTAI or at the time of FTAI without receiving GnRH (the premated group) had greater ( $P$ $<0.001)$ 7-d CR (44.7\%; 95\% CI: 38.7-50.7\%) than the remainder (23.5\%; 95\% CI: $19.8-27.2 \%)$. Duration of progesterone device insertion did not affect 7-d CR $(P=0.147)$, the 6 -d groups having a mean 7 -d CR of $35.1 \%$ (95\% CI: $29.7-40.5 \%)$ and the 7-d groups having a mean 7 -d CR of $31.5 \%$ (95\% CI: $26.9-36.1 \%$ ). However, we observed an interaction between duration of progesterone device insertion and the premated group $(P=0.023)$, such that the effect of the 7 -d treatment was lessened in the non-premated group (Table 3). The effect of eCG was also more pronounced in older cows than in younger cows $(P=0.033$; Table 4$)$. The crude 7-d CR for these interactions is presented in Tables 3 and 4 .

\section{8-d ICR}

The 28-d ICR was greater in the eCG-treated group (58.6\%, 95\% CI: $53.7-63.5 \%)$ than in the non-eCGtreated group (52.3\%, 95\% CI: $47.3-57.3 \% ; P=0.006)$, greater in cows calved longer than $42 \mathrm{~d}(62.7 \%$; $95 \% \mathrm{CI}$ : 59.9-65.6) than in cows calved less than $43 \mathrm{~d}(48.0 \%$; 95\% CI: $39.9-56.0 ; P<0.001)$, and greater in cows aged 2 yr $(60.1 \% ; 95 \%$ CI: $54.1-66.1)$ than in cows aged 3 to 5 yr $(52.9 \% ; 95 \%$ CI $48.0-57.8)$ or in cows aged $6 \mathrm{yr}$ and over $(53.3 \% ; 95 \%$ CI: $47.6-59.0 \% ; P=0.045)$. The group of cows seen in estrus and mated either before FTAI or at the time of FTAI without receiving GnRH had greater 28-d ICR (66.5\%; 95\% CI: $61.1-71.9 \%)$ than the remainder $(43.9 \%$; $95 \%$ CI: $39.6-48.2 \% ; P<$ 0.001). Duration of progesterone device insertion did

Table 3. Numbers of cows and crude 7-d conception rate (7-d CR) and 28-d in-calf rate (28-d ICR) for premating groups stratified by progesterone treatment length

\begin{tabular}{lcccccc}
\hline Premated $^{1}$ & $\begin{array}{c}\mathrm{P} 4 \\
\text { length }^{2}(\mathrm{~d})\end{array}$ & $\begin{array}{c}\text { Total } \\
\text { cows }\end{array}$ & $\begin{array}{c}\text { No. of cows } \\
\text { in calf at } 7 \mathrm{~d}\end{array}$ & $\begin{array}{c}\text { 7-d } \\
\mathrm{CR}^{3}(\%)\end{array}$ & $\begin{array}{c}\text { No. of cows } \\
\text { in calf at 28 d }\end{array}$ & $\begin{array}{c}\text { 28-d } \\
\text { ICR }^{4}(\%)\end{array}$ \\
\hline Yes & 6 & 214 & 110 & 51.4 & 150 & 70.1 \\
& 7 & 270 & 135 & 50.0 & 195 & 72.2 \\
No & 6 & 732 & 235 & 32.1 & 391 & 53.4 \\
& 7 & 775 & 181 & 23.4 & 345 & 44.5 \\
\hline
\end{tabular}

${ }^{1}$ Cows detected in heat and mated between progesterone device removal and planned fixed-time AI.

${ }^{2}$ Duration of insertion of progesterone (P4) device.

${ }^{3}$ Proportion conceiving within $7 \mathrm{~d}$ following treatment program for anestrus.

${ }^{4}$ Proportion pregnant within $28 \mathrm{~d}$ following treatment program for anestrus. 
Table 4. Results (estimated marginal means, 95\% CI) from a generalized estimating equation model for proportion of cows conceiving within $7 \mathrm{~d}\left(7-\mathrm{d} \mathrm{CR}^{1}\right)$ of a $\mathrm{GPG} / \mathrm{P} 4^{2}$ treatment regimen $(\mathrm{n}=1,991$ cows $)$ from 15 farms in Southland, New Zealand

\begin{tabular}{|c|c|c|c|c|c|c|}
\hline \multirow[b]{2}{*}{ Variable } & \multirow[b]{2}{*}{ Value } & \multirow[b]{2}{*}{$x^{2}$} & \multirow[b]{2}{*}{$P$-value } & \multirow{2}{*}{$\begin{array}{l}\mathrm{EMM}^{3} \text { for } \\
\text { 7-d CR }\end{array}$} & \multicolumn{2}{|c|}{$95 \% \mathrm{CI}$} \\
\hline & & & & & Lower & Upper \\
\hline \multirow[t]{2}{*}{$\mathrm{P} 4$ duration $(\mathrm{Tx})^{4}$} & $6 \mathrm{~d}$ & \multirow[t]{2}{*}{2.106} & \multirow[t]{2}{*}{0.147} & 0.351 & 0.297 & 0.405 \\
\hline & $7 \mathrm{~d}$ & & & 0.315 & 0.269 & 0.361 \\
\hline \multirow[t]{2}{*}{$\mathrm{eCG}^{5}$} & Control & \multirow[t]{2}{*}{5.290} & \multirow[t]{2}{*}{0.021} & 0.306 & 0.258 & 0.355 \\
\hline & Treatment & & & 0.360 & 0.310 & 0.410 \\
\hline \multirow[t]{3}{*}{ Age group } & $2 \mathrm{yr}$ & \multirow[t]{3}{*}{13.616} & \multirow[t]{3}{*}{0.001} & 0.397 & 0.334 & 0.460 \\
\hline & $3-5 \mathrm{yr}$ & & & 0.325 & 0.278 & 0.372 \\
\hline & $>5 \mathrm{yr}$ & & & 0.281 & 0.230 & 0.332 \\
\hline \multirow[t]{2}{*}{ Calved } & $<43 \mathrm{~d}$ & \multirow[t]{2}{*}{8.638} & \multirow{2}{*}{0.003} & 0.273 & 0.200 & 0.346 \\
\hline & $>42 \mathrm{~d}$ & & & 0.398 & 0.370 & 0.426 \\
\hline \multirow[t]{2}{*}{ Premated $^{6}$} & Yes & \multirow[t]{2}{*}{77.746} & \multirow[t]{2}{*}{$<0.001$} & 0.447 & 0.387 & 0.507 \\
\hline & No & & & 0.235 & 0.198 & 0.272 \\
\hline \multirow{3}{*}{$\begin{array}{l}\text { Tx } \times \text { premated } \\
6 \mathrm{~d}\end{array}$} & & \multirow[t]{5}{*}{5.195} & \multirow[t]{5}{*}{0.023} & & & \\
\hline & Premated & & & 0.436 & 0.356 & 0.517 \\
\hline & Control & & & 0.274 & 0.228 & 0.320 \\
\hline \multirow[t]{2}{*}{$7 \mathrm{~d}$} & Premated & & & 0.458 & 0.389 & 0.528 \\
\hline & Control & & & 0.200 & 0.162 & 0.238 \\
\hline $\mathrm{eCG} \times$ age group & & \multirow[t]{7}{*}{6.846} & \multirow[t]{7}{*}{0.033} & & & \\
\hline \multirow[t]{3}{*}{ Control } & $2 \mathrm{yr}$ & & & 0.416 & 0.335 & 0.498 \\
\hline & $3-5 \mathrm{yr}$ & & & 0.277 & 0.224 & 0.329 \\
\hline & $>5 \mathrm{yr}$ & & & 0.240 & 0.182 & 0.299 \\
\hline \multirow[t]{3}{*}{ eCG } & $2 \mathrm{yr}$ & & & 0.377 & 0.300 & 0.454 \\
\hline & $3-5$ yr & & & 0.378 & 0.319 & 0.436 \\
\hline & $>5 \mathrm{yr}$ & & & 0.326 & 0.257 & 0.394 \\
\hline
\end{tabular}

${ }^{1}$ Proportion conceiving within $7 \mathrm{~d}$ following treatment program for anestrus.

${ }^{2}$ Anestrous treatment program utilizing insertion of progesterone device, administration of $100 \mu \mathrm{g}$ of gonadorelin at the time of progesterone device insertion and at $60 \mathrm{~h}$ after device removal, and $500 \mu \mathrm{g}$ of sodium cloprostenol at the time of device removal.

${ }^{3}$ Estimated marginal means.

${ }^{4}$ Duration of insertion of progesterone device.

${ }^{5}$ Equine chorionic gonadotropin given at time of progesterone device removal.

${ }^{6}$ Cows detected in estrus and mated from device removal to fixed-time AI.

not alter 28 -d ICR $(P=0.558)$, but we observed a similar interaction between treatment duration and the premated group $(P=0.016$; Table 5$)$ as in the 7 -d $\mathrm{CR}$, such that the effect of the 7-d treatment was much lessened in the non-premated group (Table 3).

\section{DTC}

The mean and median DTC from the time of removal of progesterone device were 37.6 and $24.0 \mathrm{~d}$, respectively. Days to conception was longer in non-eCG-treated cows than in eCG-treated cows $(P=0.011 ; \beta=1.168)$, and was influenced by days calved $(P<0.001)$, farm $(P$ $<0.001)$, and premating $(P<0.001)$. Cows calved less than $43 \mathrm{~d}$ took 1.60 times more days to conceive than cows calved more than $42 \mathrm{~d}$.

\section{DISCUSSION}

\section{Effect of eCG}

The addition of eCG to the GPG/P4 regimen significantly improved all reproductive outcomes in this study. The differences in reproductive performance between the eCG-treated groups and the control groups were maintained from 7 to $28 \mathrm{~d}$, as determined by the similar differences in 7-d CR and 28-d ICR between groups.

Equine chorionic gonadotropin has been used previously in the treatment of AnA in New Zealand; cows received treatment with an 8 -d progesterone-releasing device-based protocol, a 10-mg EB capsule at device insertion, and 400 IU of eCG at device removal, starting 10 d before PSM. A 17-d ICR of $39.3 \%$ was reported 
Table 5. Results (estimated marginal means, 95\% CI) from a generalized estimating equation model for proportion of cows found in calf within $28 \mathrm{~d}(28 \text {-d in-calf rate })^{1}$ of a GPG $/ \mathrm{P} 4^{2}$ treatment regimen $(\mathrm{n}=1,991$ cows) from 15 farms in Southland, New Zealand

\begin{tabular}{|c|c|c|c|c|c|c|}
\hline \multirow[b]{2}{*}{ Variable } & \multirow[b]{2}{*}{ Value } & \multirow[b]{2}{*}{$x^{2}$} & \multirow[b]{2}{*}{$P$-value } & \multirow[b]{2}{*}{$\mathrm{EMM}^{3}$} & \multicolumn{2}{|c|}{$95 \% \mathrm{CI}$} \\
\hline & & & & & Lower & Upper \\
\hline $\mathrm{P} 4$ duration $(\mathrm{Tx})^{4}$ & $\begin{array}{l}6 \mathrm{~d} \\
7 \mathrm{~d}\end{array}$ & 0.343 & 0.558 & $\begin{array}{l}0.563 \\
0.546\end{array}$ & $\begin{array}{l}0.508 \\
0.497\end{array}$ & $\begin{array}{l}0.618 \\
0.596\end{array}$ \\
\hline $\mathrm{eCG}^{5}$ & $\begin{array}{l}\text { Control } \\
\text { Treatment }\end{array}$ & 7.523 & 0.006 & $\begin{array}{l}0.523 \\
0.586\end{array}$ & $\begin{array}{l}0.473 \\
0.537\end{array}$ & $\begin{array}{l}0.573 \\
0.635\end{array}$ \\
\hline Age group & $\begin{array}{l}2 \mathrm{yr} \\
3-5 \mathrm{yr} \\
>5 \mathrm{yr}\end{array}$ & 6.191 & 0.045 & $\begin{array}{l}0.601 \\
0.529 \\
0.533\end{array}$ & $\begin{array}{l}0.541 \\
0.480 \\
0.476\end{array}$ & $\begin{array}{l}0.661 \\
0.578 \\
0.590\end{array}$ \\
\hline Calved & $\begin{array}{l}<43 \mathrm{~d} \\
>42 \mathrm{~d}\end{array}$ & 12.730 & $<0.001$ & $\begin{array}{l}0.480 \\
0.627\end{array}$ & $\begin{array}{l}0.399 \\
0.599\end{array}$ & $\begin{array}{l}0.560 \\
0.656\end{array}$ \\
\hline Premated $^{6}$ & $\begin{array}{l}\text { Yes } \\
\text { No }\end{array}$ & 66.119 & $<0.001$ & $\begin{array}{l}0.665 \\
0.439\end{array}$ & $\begin{array}{l}0.611 \\
0.396\end{array}$ & $\begin{array}{l}0.719 \\
0.482\end{array}$ \\
\hline $\begin{array}{l}\text { Tx } \times \text { premated } \\
6 \mathrm{~d} \\
7 \mathrm{~d}\end{array}$ & $\begin{array}{l}\text { Premated } \\
\text { Control } \\
\text { Premated } \\
\text { Control }\end{array}$ & 5.772 & 0.016 & $\begin{array}{l}0.641 \\
0.481 \\
0.687 \\
0.397\end{array}$ & $\begin{array}{l}0.564 \\
0.430 \\
0.625 \\
0.349\end{array}$ & $\begin{array}{l}0.718 \\
0.533 \\
0.750 \\
0.446\end{array}$ \\
\hline
\end{tabular}

${ }^{1}$ Proportion pregnant within $28 \mathrm{~d}$ following treatment program for anestrus.

${ }^{2}$ Anestrous treatment program utilizing insertion of progesterone device, administration of $100 \mu \mathrm{g}$ of gonadorelin at the time of progesterone device insertion and at $60 \mathrm{~h}$ after device removal, and $500 \mu \mathrm{g}$ of sodium cloprostenol at the time of device removal.

${ }^{3}$ Estimated marginal means.

${ }^{4}$ Duration of insertion of progesterone device.

${ }^{5}$ Equine chorionic gonadotropin given at time of progesterone device removal.

${ }^{6}$ Cows detected in estrus and mated from device removal to fixed-time AI.

(Xu et al., 1997). We have recently reported a 7-d ICR of $44.4 \%$ following the use of eCG in an 8-d P4/EB program compared with $34.8 \%$ in the control group (without eCG) in AnA dairy cows in New Zealand (Bryan et al., 2010).

In South American pasture-based lactating beef and dairy cattle, the use of eCG in a conventional progesterone device/EB FTAI protocol has been reported to increase pregnancy rates by 10 to $15 \%$ compared with the same protocol without eCG (Cutaia et al., 2003; Veneranda et al., 2006, 2008). Equine chorionic gonadotropin has been reported to benefit a standard GPG synchrony program (Baruselli et al., 2004; Small et al., 2009), and in cycling cattle, a 6.5-d progesterone program with EB plus eCG resulted in pregnancy rates of $49.1 \%$ compared with $22.2 \%$ when eCG was not used (Fuentes and De la Fuente, 1997). The use of eCG in conjunction with $\mathrm{P} 4$ devices has also been demonstrated to increase pregnancy rates in embryo transfer recipients (reviewed in Bó et al., 2002 and Baruselli et al., 2010).

Other data on eCG are mixed. In cycling Bos taurus beef heifers, adding eCG to a fixed-time AI synchroni- zation protocol showed no benefit (Small et al., 2010). The treatment of lactating dairy cows with eCG has also been studied in a freestall system in Brazil (Souza et al., 2009). Administration of eCG at the time of CIDR removal in an estradiol-based synchronization treatment did not increase the size of the ovulatory follicle, and pregnancy rates were only significantly improved in cows with a BCS $<2.75$. In a study involving lactating beef cattle in Canada (Small et al., 2009), most of which were cycling at the time of treatment, the use of eCG in a GnRH-based protocol increased pregnancies per insemination only in primiparous cows that had not been presynchronized. It may be that the use of eCG is of greater benefit when cyclicity, age, and nutritional status are likely to limit breeding success.

Equine chorionic gonadotropin is produced by the endometrial cups of the pregnant mare between 40 and $130 \mathrm{~d}$ of pregnancy (Murphy and Martinuk, 1991). It binds to both LH and FSH receptors of the follicle in cattle (Soumano et al., 1998), LH receptors of the CL in the mare (Stewart and Allen, 1979), and has been demonstrated to bind to, and inhibit the binding of, LH to granulosa, luteal, and Leydig cell preparations 
in several species (reviewed by Murphy and Martinuk, 1991). These effects on the development and maturation of the ovulatory follicle may help to explain the improvements in reproductive performance seen in this and other studies.

It has also been demonstrated that eCG exerts its effects by increasing the development and size of the ovulatory follicle in anestrous beef cattle (Baruselli et al., 2004; Sá Filho et al., 2010). Furthermore, eCG treatment has been demonstrated to result in a CL of greater volume in embryo transfer recipients (Bó et al., 2002) and greater progesterone concentrations in beef cattle (reviewed in Baruselli et al., 2004). Souza et al. (2009) also reported a tendency for greater progesterone concentrations in high-producing dairy cows. Collectively, these factors are hypothesized to improve reproductive performance by improving conception rates and early embryonic survival.

We observed no interaction between eCG treatment and length of progesterone treatment. However, we did observe a first-order interaction with eCG treatment and age, in that older cows $(3-5 \mathrm{yr}$ and $\geq 6 \mathrm{yr})$ had a significantly greater 7-d CR following treatment with eCG than did younger cows. It is interesting that this interaction was not present for 28-d ICR. A similar beneficial effect of eCG was reported in older cows treated with $\mathrm{P} 4 / \mathrm{EB}$ protocols; cows more than 5 yr of age had significantly improved reproductive outcomes with the addition of $\mathrm{eCG}$ at the time of progesterone device removal (Bryan et al., 2010), and Beggs and Kelly (2010) reported a similar benefit for the use of eCG in a GPG (no progesterone) protocol used on pasture-based cycling dairy cows in Australia.

\section{Effect of the Progesterone Device}

Responses did not differ between the 2 progesterone device treatment periods, and we observed no interaction between eCG treatment and progesterone device treatment period, indicating that either 6 or $7 \mathrm{~d}$ of progesterone treatment was adequate. At a univariate level, data indicated the possible presence of a farm management/breed-type interaction with the duration of progesterone treatment; farms where cows had a greater proportion of their diet as supplementary feed (silage, concentrate) appeared to be more responsive to a 6 -d progesterone device protocol. In general, these farms also had higher producing cows and the cows were of a Holstein-Friesian breed-type rather than the typical New Zealand Jersey/Friesian crossbred cow. However, this effect disappeared in the multivariate analysis, and further study would be required to determine whether this effect was real.
The AnA syndrome in New Zealand was first described over 30 yr ago by Fielden et al. (1973) and, although progesterone device periods have varied, progesterone devices have been used successfully to treat AnA for almost 20 yr (Macmillan and Peterson, 1993). The original protocol was described by Rhodes et al. (1998), further developed by the addition of an injection of $2 \mathrm{mg}$ of EB at the time of insertion of progesterone device (Verkerk et al., 1998), and more recently by extending the use of the progesterone device to $8 \mathrm{~d}$ with a further injection of $1 \mathrm{mg}$ of EB $24 \mathrm{~h}$ after device removal to induce estrus and ovulation (McDougall, 2001).

Although the GPG protocol for treatment of AnA has been used in many countries (Pursley et al., 1997; Peters and Pursley, 2002), its use has been limited in New Zealand, where its efficacy without the addition of a progesterone device has been questioned (Rhodes et al., 2003). The only controlled field study comparing GPG with progesterone or EB had insufficient numbers to detect a difference (McDougall et al., 2001). The apparent difference in response to GPG may be due to subtle variations in etiology; milk production appears to be a more important risk factor in the development of AnA in North America and Europe than in New Zealand (Macmillan et al., 1996), where nutritional restrictions under pasture-based systems appear to be a higher risk factor (Macmillan, 2002; Boland, 2005).

Lamb et al. (2001) reported that the use of a 7-d progesterone device within a $\mathrm{GnRH}$-based regimen ( $\mathrm{GnRH}$ administration and progesterone device on $\mathrm{d}$ 0 , removal of the device and administration of $\mathrm{PGF}_{2 \alpha}$ on d 7, GnRH on d 9; GPG/P4) resulted in higher pregnancy rates in lactating, anestrous beef cattle than did GPG alone. In New Zealand, recent work has demonstrated that the use of a GPG/P4 program improves reproductive performance compared with a standard GPG regimen (McDougall, 2010).

\section{CONCLUSIONS}

Under pasture-based conditions in New Zealand, the treatment of cows in AnA with a progesterone plus GnRH-based protocol, which included 400 IU of eCG at the time of progesterone device removal, significantly improved all reproductive outcomes. We found no difference in any of the measureable outcomes between the 6- or 7-d protocols, and no eCG by progesterone device length interaction was observed. Cows detected in estrus and inseminated from the time of progesterone device removal until FTAI had a greater probability of conceiving (as determined by significantly greater 7 -d CR). Herds with a greater proportion of cows detected 
in estrus between progesterone device removal and FTAI also had greater 7-d CR. The effect of eCG on 7 -d CR was greater in cows aged 3 yr or older than in 2-yr-old cows.

\section{REFERENCES}

Baruselli, P. S., R. M. Ferreira, M. F. Sá Filho, L. F. T. Nasser, C. A Rodrigues, and G. A. Bó. 2010. Bovine embryo transfer recipient synchronization and management in tropical environments. Reprod. Fertil. Dev. 22:67-74.

Baruselli, P. S., E. Reis, M. O. Marques, L. Nasser, and G. A. Bo. 2004. The use of hormonal treatments to improve reproductive performance of anestrous beef cattle in tropical climates. Anim. Reprod. Sci. 82-83:479-486.

Beggs, D. S., and J. C. Kelly. 2010. Pilot trial-The effect of eCG given as part of an Ovsynch protocol in a whole herd synchrony program on a seasonal calving herd in Victoria. Aust. Cattle Vet. $55: 14-17$

Bó, G. A., P. S. Baruselli, D. Moreno, L. Cutaia, M. Caccia, R. Tríbulo, H. Tríbulo, and R. J. Mapletoft. 2002. The control of follicular wave development for self-appointed embryo transfer programs in cattle. Theriogenology 57:53-72.

Boland, M. P. 2005. Impact of current management practices on embryo survival in the modern dairy cow. Ir. Vet. J. 58:515-519.

Bryan, M. A., G. A. Bo, C. Heuer, and F. R. Emslie. 2010. Use of equine chorionic gonadotropin in synchronised AI of seasonalbreeding, pasture-based, anoestrous dairy cattle. Reprod. Fertil. Dev. 22:126-131.

Cutaia, L., R. Tribulo, D. Moreno, and G. A. Bo. 2003. Pregnancy rate in lactating beef cows treated with progesterone-releasing devices, estradiol benzoate and equine chorionic gonadotropin (eCG). Theriogenology 59:216. (Abstr.)

Day, A. M., and K. L. Macmillan. 1995. CIDR update and beyond. Pages 136-143 in Proc. NZ Dairy Cattle Vet Conf., New Plymouth, New Zealand. VetLearn Foundation, Palmerston North, New Zealand.

Fielden, E. D., K. L. Macmillan, and J. D. Watson. 1973. The anoestrus syndrome in New Zealand dairy cattle. N. Z. Vet. J. 21:77-81.

Freedman, L. S. 1982. Tables of the number of patients required in clinical trials using the log rank test. Stat. Med. 1:121-129.

Fuentes, S., and J. De la Fuente. 1997. Different synchronization treatments for direct embryo transfer to recipients heifers. Abstract 148 in Proc. XIII Annual Meeting of the European Embryo Transfer Association (AETE), Lyon, France. AETE, Lyon, France.

Hanlon, D. W., J. J. Wichtel, Z. Z. Xu, and L. J. Burton. 2000. The reproductive performance of anoestrus dairy cows following treatment with progesterone and oestradiol prior to the start of mating. N. Z. Vet. J. 48:136-143.

Lamb, G. C., J. S. Stevenson, D. J. Kesler, H. A. Garverick, D. R Brown, and B. E. Salfen. 2001. Inclusion of an intravaginal progesterone insert plus GnRH and prostaglandin F2 $\alpha$ for ovulation control in postpartum suckled beef cows. J. Anim. Sci. 79:2253-2259.

Lane, E. A., E. J. Austin, and M. A. Crowe. 2009. Oestrous synchronisation in cattle - Current options following the EU regulations restricting use of oestrogenic compounds in food-producing animals: A review. Anim. Reprod. Sci. 109:1-16.

Macdonald, K. A., and K. L. Macmillan. 1993. Condition score and liveweight in Jersey and Friesian cows. Pages 47-50 in Proc. 45th Ruakura Farmers' Conf. Dairying Research Corp., Hamilton, New Zealand.

Macmillan, K. L. 2002. Advances in bovine theriogenology in New Zealand. 1. Pregnancy, parturition and the postpartum period. N. Z. Vet. J. 50(Suppl.):67-73.

Macmillan, K. L.. I. J. Lean, and C. T. Westwood. 1996. A review of relationships involving milk yield, energy balance, blood metabolites and reproductive performance in high-yielding dairy cows. Aust. Vet. J. 73:141-147.
Macmillan, K. L., and A. J. Peterson. 1993. A new intravaginal progesterone releasing device in cattle (CIDR-B) for oestrous synchronisation, increasing pregnancy rates and the treatment of postpartum anoestrum. Anim. Reprod. Sci. 33:1-25.

McDougall, S. 2001. Reproductive performance of anovulatory anoestrous postpartum dairy cows following treatment with two progesterone and oestradiol benzoate-based protocols, with or without resynchrony. N. Z. Vet. J. 49:187-194.

McDougall, S. 2010. Effects of treatment of anestrous dairy cows with gonadotropin-releasing hormone, prostaglandin and progesterone. J. Dairy Sci. 93:1944-1959.

McDougall, S., A. A. Cullum, F. M. Anniss, and F. M. Rhodes. 2001. Treatment of anovulatory anoestrous postpartum dairy cows with a gonadotropin-releasing hormone $(\mathrm{GnRH})$, prostaglandin $\mathrm{F} 2 \boldsymbol{\alpha}$, GnRH regimen or with progesterone and oestradiol benzoate. N. Z. Vet. J. 49:168-172.

McDougall, S., C. W. R. Compton, D. W. Hanlon, P. J. Davidson, D. J. Sullivan, A. H. Gore, and F. M. Anniss. 2005. Reproductive performance in anoestrous dairy cows following treatment with two protocols and two doses of progesterone. Theriogenology $63: 1529-1548$

Morris, C. A., and A. M. Day. 1994. The relationship between estimates of ovarian size in live cattle and subsequent measurements post mortem. N. Z. Vet. J. 42:185-186.

Murphy, B. D., and S. D. Martinuk. 1991. Equine chorionic gonadotropin. Endocr. Rev. 12:27-44.

Peters, M. W., and J. R. Pursley. 2002. Fertility of lactating dairy cows treated with Ovsynch after presynchronization injections of $\mathrm{PGF}_{2 \mathrm{\alpha}}$ and GnRH. J. Dairy Sci. 85:2403-2406.

Pursley, J. R., M. R. Kosorok, and M. C. Wiltbank. 1997. Reproductive management of lactating dairy cows using synchronization of ovulation. J. Dairy Sci. 80:301-306.

Rhodes, F. M., S. McDougall, C. R. Burke, G. A. Verkerk, and K. L. Macmillan. 2003. Treatment of cows with an extended postpartum anoestrous interval. J. Dairy Sci. 86:1876-1894.

Rhodes, F. M., B. A. Clark, D. P. Nation, V. K. Taufa, M. L. Day, K. L. Macmillan, and S. McDougall. 1998. Treatment of postpartum anoestrus in New Zealand dairy cows with progesterone and oestradiol benzoate. Proc. 20th World Buiatrics Congr. 2:607-612. Australian Association of Cattle Veterinarians, Sydney, Australia.

Sá Filho, M. F., H. Ayres, R. M. Ferreira, M. O. Marques, E. L. Reis, R. C. P. Silva, C. A. Rodrigues, E. H. Madureira, G. A. Bó, and P. S. Baruselli. 2010. Equine chorionic gonadotropin and gonadotropin-releasing hormone enhance fertility in a norgestomet-based, timed artificial insemination protocol in suckled Nelore (Bos indicus) cows. Theriogenology 73:651-658.

Small, J. A., M. G. Colazo, J. P. Kastelic, N. E. Erickson, and R. J. Mapletoft. 2010. Effects of presynchronization and eCG on pregnancy rates to GnRH-based, fixed-time artificial insemination in beef heifers. Can. J. Anim. Sci. 90:23-34.

Small, J. A., M. G. Colazo, J. P. Kastelic, and R. J. Mapletoft. 2009. Effects of progesterone presynchronization and eCG on pregnancy rates to GnRH-based, timed-AI in beef cattle. Theriogenology 71:698-706.

Smith, J. F., and K. L. Macmillan. 1978. The applied and economic aspects of oestrus synchronisation in cattle. N. Z. Vet. J. 26:173175 .

Soumano, K., J. G. Lussier, and C. A. Price. 1998. Levels of messenger RNA encoding ovarian receptors for FSH and $\mathrm{LH}$ in cattle during superovulation with equine chorionic gonadotropin versus FSH. J. Endocrinol. 156:373-378.

Souza, A., S. Viechnieski, F. A. Lima, F. F. Silva, R. Araujo, G. A. Bo, M. C. Wiltbank, and P. Baruselli. 2009. Effects of equine chorionic gonadotropin and type of ovulatory stimulus in a timed-AI protocol on reproductive responses in dairy cows. Theriogenology $72: 10-21$.

Stewart, F., and W. Allen. 1979. The binding of FSH, LH and PMSG to equine gonadal tissues. J. Reprod. Fertil. Suppl. 27:431-440.

Veneranda, G., L. Filippi, D. Racca, L. Cutaia, and G. A. Bo. 2008. Pregnancy rates in dairy cows treated with intravaginal progester- 
one devices and GnRH or estradiol benzoate and eCG. Reprod. Fertil. Dev. 20:91. (Abstr.)

Veneranda, G., L. Filippi, D. Racca, G. Romero, E. Balla, L. Cutaia, and G. A. Bo. 2006. Pregnancy rates in dairy cows treated with intravaginal progesterone devices and different fixed-time AI protocols. Reprod. Fertil. Dev. 18:118. (Abstr.)

Verkerk, G., V. K. Taufa, S. Morgan, B. A. Clark, and K. L. Macmillan. 1998. Effects of oestradiol benzoate by injection at CIDR $^{\text {TM }}$ insertion for the treatment of postpartum anovulatory anoestrus in dairy cows. Proc. N. Z. Soc. Anim. Prod. 58:82-84.

Westwood, C. T., I. J. Lean, and J. K. Garvin. 2002. Factors influencing fertility of Holstein dairy cows: A multivariate description. J. Dairy Sci. 85:3225-3237.

Xu, Z. Z., L. J. Burton, and K. L. Macmillan. 1997. Treatment of postpartum anoestrous dairy cows with progesterone, oestradiol and equine chorionic gonadotropin. N. Z. Vet. J. 45:205-207. 